\title{
Political Economy of Poverty in Turkey ${ }^{1}$
}

Tartk ILIMAN, Department of Public Finance, Faculty of Economics and Administrative Sciences, Adnan Menderes University, Turkey; e-mail: tarikiliman@ hotmail.com

Recep TEKELI, Department of Public Finance, Faculty of Economics and Administrative Sciences, Adnan Menderes University, Turkey; e-mail: rtekeli@adu.edu.tr

\section{Türkiye'de Yoksulluğun Politik İktisadı ${ }^{2}$}

\begin{abstract}
While the fight against poverty is continuing in the world, secondary income distribution has regarded as an effective way in fighting against poverty in Turkey. For that purpose, the special fund called as "Social Aid and Solidarity Promotion Fund" established in 1986. Primarily this fund is a kind of social transfer expenditure and it aims at helping poor people directly. Although special funds as social direct expenditures utilized as the most effective instrument to combat poverty, allocation of the funds could be at the government's discretion. Because of the unclear and subjective criteria in the fund allocation, it is possible that politicians to maximize their interests in the political arena can use the fund. Therefore, the government in Turkey might incline to manipulate the (social) public expenditures to maximize their interests and enhance the re-election chances in terms of political economy. This paper assesses empirically the relationship between "Social Aid and Solidarity Promotion Fund" (SASPF) and political economic factors within political-economy context. In this study, using 81 provincial level data, we find that funds, as social expenditures could be vital tools for politicians to maximize their political interests.
\end{abstract}

Keywords $\quad$ : Poverty, Political Economy, Pork-Barrel Politics, Special Funds.

JEL Classification Codes : H50, I38, D72.

Öz

Dünyada yoksullukla mücadele devam ederken, ikincil gelir dağıtımı Türkiye'de yoksulluğa karşı mücadelede etkin bir yol olarak kabul edilmiştir. Bu amaçla, "Sosyal Yardımlaşma

I This article is the revised and extended version of the paper presented in "First International Annual Meeting of Sosyoekonomi Society" which was held by Sosyoekonomi Society and CMEE - Center for Market Economics and Entrepreneurship of Hacettepe University, in Munich/Germany, on October 29-30.

2 Bu makale Sosyoekonomi Derneği ile Hacettepe Üniversitesi Piyasa Ekonomisini ve Girişimciliği Gelişstirme Merkezi tarafindan Almanya'nın Münih șehrinde, 29-30 Ekim 2015 tarihlerinde düzenlenen "Birinci Uluslararası Sosyoekonomi Derneği Ylllık Buluşması"nda sunulan çalışmanın gözden geçirilmişs ve genişletilmiş halidir. 
ve Dayanışmayı Teşvik Fonu” olarak adlandırılan özel fon 1986 yılında kurulmuştur. Öncelikle bu fon sosyal transfer harcamaları şeklindedir ve doğrudan yoksul insanlara yardımcı olmayı amaçlamaktadır. Doğrudan sosyal harcamaları olarak özel fonlar yoksullukla mücadele için en etkili araç olarak kullanılmasına rağmen, fon tahsisi hükümetin ihtiyari karar verme yetkisine bağlı olabilir. Fon tahsisindeki belirsiz ve subjektif kriterlerden dolayı bu fon politik arenada kendi faydasını maksimize etmek için politikacılar tarafından kullanılması mümkündür. Bu nedenle, Türkiye'de politik-ekonomi bakımından hükümet kendi faydasını maksimize etmek ve yeniden seçilme şansını arttırmak için (sosyal) kamu harcamalarını maniple etmeye meyledebilir. Bu makale politik-ekonomi bağlamında "Sosyal Yardımlaşma ve Dayanışmayı Teşvik Fonu" (SASPF) ve siyasi ekonomik faktörler arasındaki ilişkiyi ampirik olarak değerlendirmektedir. Bu çalışmada, 81 il düzeyinde veriler kullanılarak, siyasetçilerin kendi politik yararlarını maksimize etmek için sosyal harcamalar olarak fonların önemli araçlar olabileceği bulunmuştur.

Anahtar Sözcükler $\quad$ : Yoksulluk, Politik İktisat, Yandaş Siyaset, Özel Fonlar.

\section{Introduction}

Poverty is an issue, which has existed since the beginning of the human history. Poverty is not only a problem for less-developed countries but also a problem for both developing and developed countries because of the ongoing rapid globalization trend for last quarter of a century. There are two types of discussions about the concept of poverty. The first one focuses on an appropriate definition of poverty and its measurement. The second one addresses how to struggle with poverty. Poverty has perceived as a globalization issue since 1990s and it has observed that the international institutions like the International Monetary Fund and the World Bank have intended to contribute more on the issue of poverty. Secondary income distribution has used to deal with the issue of poverty in Turkey and it considered that this was the most effective strategy. For that purpose, the special fund called as "Social Aid and Solidarity Promotion Fund" established in 1986. Primarily the fund is a kind of social transfer expenditure and it aims at helping poor people directly. In addition, it can said that the fund improves the income distribution indirectly since it has some potential to improve income distribution. However, because of the unclear and subjective criteria to allocate the fund, it is possible that politicians to maximize their interests in political arena could use the fund.

In this context, this study comprises three sections. In the first section, the concept of poverty explained. This section also focuses on the instruments, which fosters the struggles against poverty. These instruments addressed specifically to direct and indirect strategies for the alleviation of poverty.

Second section analysis the poverty level and the specific funds used to combat against poverty in Turkey. In the third section, after reviewing the literature, the relationship between economical- political variables and "Social Aid and Solidarity Promotion Fund" analyzed. In this section, we examine whether there is an interaction between political variables, "Social Aid, and Solidarity Promotion Fund" which is supposed to be used in the struggle against poverty in Turkey. 


\section{The Concept and Alleviation of Poverty}

Poverty alleviation has been a main concern of development economics (Besley, 1996) and as a distinct research area Economics of Poverty has been identified by JEL since 1969 (Beker, 2016). The poverty as a concept has atracted many interests in the literature and the focus has been on the definition who poor are? and how can poverty be defined?

Goedhart et al. (1977) defines the term poor as "in simpler language, ... welfare is defined in terms of command over real goods and services-command over resources... The less command one has over resources, the less welfare one enjoys; that is, the poorer one is". Then, they defined the concept as "a situation where command over resources falls below a certain level, the poverty line". Beker (2016) also defines poor as those "who do not have the basic necessities that they need to lead a reasonable life - food, shelter, and clothing". Therefore, stemming from these definition, poor people can be defined as those who do not earn an income at all or those who do not earn an income that is sufficient to satisfy their basic needs (Beker, 2016). Income level of people is directly related to the concept since "lack of income generally coincides with inadaquate social conditions: the poor suffer from high child mortality, poor health, and limited education" (Rapatsa, 2015: 43).

Poverty, as a problem for the whole world, is so complex that it observed in different forms in every country. According to Rowentree, if people have squalid lifestyle, too little money and a lack of physical subsistence, then they absolutely do not have enough ability to keep their lives. Therefore, these people counted in "primary poverty" (Wilson, 2002: 538). Typically, poverty means that individuals do not have enough resources or abilities to meet their needs (Coudouel et al, 2002: 29).

It should be noted that "poverty has many dimensions such as inadequate incomes, malnutrition, lack of access to social services, and lack of social and political status" (Walton, 1990). Therefore, how can we distinguish who is poor and who is not poor? To do so the level of the poverty line that be defined. It can be defined as the level of command over resources below which an individual becomes poor (Goedhart et al 1977). According to Beker (2016), the poverty line measures "the amount of money needed to buy the basket of commodities necessary to satisfy the socially determined basic needs in that country at that time. This may be an absolute value or a relative one" (Beker, 2016: 14) In line with the World Bank'view, Kehler (2001) sees poverty with reference to inability to attain minimum standard of living, which is measured in terms of basic needs or income required to meet such needs (Rapatsa, 2015: 43).

Measurement of poverty is an important issue because it has a direct impact on policies to alleviate poverty problem. If poverty is measured in relative terms, it can be ameliorated with changing the income distribution. This is because relative poverty measures inequality within the bottom half of the income distribution, and hence it may be 
reduced with improving income distribution (Beker, 2016). However, if poverty is measured in absolute values, it may be reduced with economic growth. This is because the absolute measure assumes that poverty is related to "the amount of commodities available to an individual to satisfy the basic needs disregarding what happens to the rest of the people" (Beker 2016 :15).

Therefore, the way poverty is measured is an important policy issue because it is directly related to the policies used to address poverty. There are different strategies suggested to reduce poverty. Walton (1990) for example, argues that there are two effective strategies for reducing poverty. First strategy for the poor people includes creating of income -earning opportunities through a pattern of growth that is labor intensive. The second strategy for the poor people includes increasing their welfare level and capacity to respond to opportunities through public provision of social services (Walton, 1990).

In the same line of argument, the policy instruments designed to achieve the amelioration of poverty can be divided into two main groups: the direct approach and the indirect approach (Bhagwati, 1988). The indirect approach uses resources to accelerate economic growth. When economy grows, it has impact on the incomes and hence improves the poor's living standards. On the other hand the direct approach uses "the public provision of minimum-needs-oriented education, housing, nutritional supplements and health, and transfers to finance private expenditures on these and other components of the living standards of the poor" (Bhagwati, 1988: 539). Here, the direct approach explicitly targets the poor and the policy instruments employed can be extended further to include provision of drinking water, sanitation, transport, medical care. As it is essential both as a direct component of well-being and as an input into productive capability (Besley \& Ghatak, 2004: 1), effective delivery of these public goods and services plays a vital role in fighting poverty and may have a greater impact on improving living standards than an income increase alone (see Beker, 2016: 21).

After the World War II, the growth-oriented approach to alleviate poverty was the more pronounced instrument until the 1970s era of recession and inflation (see Bhagwati, 1988; Danziger and Weinberg, 1994). However, growth has still been seen beneficial to the poor; for example, Ravallion (1995) using a sample of 16 developing countries in the 1980s and finds that a growth in consumption lead to a reduction in the poor people. Housseima and ben Rejeb (2012) using panel on 52 developing countries, find that an increase in per capita GDP causes a reduction of the poverty rate. In addition, Foxley (2004: 1) reports that approximately 60\% of Chile's poverty eradication in the 1990 s was due to economic growth and $40 \%$ of it was attributed to social policies.

Although policies designed to foster economic growth significantly reduce poverty (see Ravallion, 1995; Bruno, et al 1995; Housseima \& ben Rejeb, 2012; Foxley, 2004; Bhagwati 1988; Danziger \& Weinberg, 1994; Datt et al 2016), policies aimed specifically at reducing poverty are also very important. Ahmad and Chalk (1993: 5) argue 
that both the level and the composition of public expenditures have important implications for poor people. Kenworthy (1999), using data on fifteen industrialized countries, assesses the effects of social-welfare policy extensiveness on poverty rates and her findings support that social-welfare programs as a direct approach reduce poverty.

Caminada et al (2012: 119) reviewing some studies reported a strong and a negative correlation between poverty and the level of social expenditures in selected European countries. Factors such as demographic and economic conditions may also have an impact on poverty, affecting the relationship between social expenditures and poverty.

Social transfers as fiscal policy instruments are important policy tools to fight against poverty. For example, using consistent household data, Heady et al (2001: 18) analyzed the comparative effects of cash transfers on inequality and poverty. They pointed that social transfers vary enormously across the EU and their findings suggest that countries that are effective in using social transfers to reduce inequality are also effective in reducing poverty.

However, it should be stressed that while social expenditures can be used to alleviate poverty, vote-maximizing politicians to further their interest in the political arena can use it. In this context, Dash et al (2012), for example, emphasize that political parties are affiliated to various interest groups. While political parties need their support to win elections, the interest groups would continue to support as long as their interests are matched. Political parties use various policies such as regular salary hikes, quick promotions for the employees, and creating fresh employment opportunities to satisfy their respective interest groups. Political parties would also use various government-sponsored programs related to poverty reduction, employment generation, public health and insurance to serve their political purposes (Dash et al, 2012).

Pop-Eleches and Pop-Eleches (2012) argue that targeted social spending programs might be effective if willingness among program beneficiaries increases to turn out in elections and support political party in power. The political benefits of programs like the computer voucher program appear to accrue primarily the parties who are in office at the time when benefits are received (see Pop-Eleches \& Pop-Eleches, 2012).

In Turkey, the special fund called as "Social Aid and Solidarity Promotion Fund" was established. Primarily, the fund aims at helping poor people directly, and since it has some potentials to improve income distribution, it can be said that the fund improves the income distribution indirectly. Next section briefly analysis poverty in Turkey and the fiscal policy instruments to fight against it. 


\section{Poverty and Special Funds in Turkey}

\subsection{Poverty Measures}

Table (1) shows the percentage of poor individuals between 2002 and 2013 in Turkey. The proportion of different poverty rates (i.e. food and non-food, per person living on less than $1 \$$ a day, less than $2,15 \$$ a day and less than $4,3 \$$ a day and expenditure-based on relative poverty) in total population between 2002 and 2013 are compared in the table.

\section{Table: 1}

\section{Percentage of Poor Individuals between 2002 and 2013 in Turkey}

\begin{tabular}{|c|c|c|c|c|c|c|c|c|c|}
\hline Turkey & $\mathbf{2 0 0 2 - 2 0 0 5}$ & $\mathbf{2 0 0 6}$ & $\mathbf{2 0 0 7}$ & $\mathbf{2 0 0 8}$ & $\mathbf{2 0 0 9}$ & $\mathbf{2 0 1 0}$ & $\mathbf{2 0 1 1}$ & $\mathbf{2 0 1 2}$ & $\mathbf{2 0 1 3}$ \\
\hline $\begin{array}{c}\text { Complete Poverty } \\
\text { (Food + Non-Food) }^{\mathbf{a}}\end{array}$ & $\mathbf{2 5 . 2 9}$ & 17.81 & 17.79 & 17.11 & 18.08 & - & - & - & - \\
\hline Below 1\$ per capita per day $^{\mathbf{a}}$ & $\mathbf{1 . 2 0}$ & - & - & - & - & - & - & - & - \\
\hline Below 2,15\$ per capita per day $^{\mathbf{a}}$ & $\mathbf{2 . 3 6}$ & 1.41 & 0.52 & 0.47 & 0.22 & 0.21 & 0.14 & 0.06 & 0.06 \\
\hline Below 4,3\$ per capita per day $^{\mathbf{a}}$ & $\mathbf{2 2 . 8 2}$ & 13.33 & 8.41 & 6.83 & 4.35 & 3.66 & 2.79 & 2.27 & 2.06 \\
\hline Relative poverty based on expenditure $^{\mathbf{b}}$ & $\mathbf{1 5 . 1 4}$ & 14.50 & 14.70 & 15.06 & 15.12 & - & - & - & - \\
\hline
\end{tabular}

Source: data obtained from TurkStat (2013) Notes: a) the current PPP values in TL are used for the equivalents of $1 \$$. b) It's based on the 50\% of equivalised median consumption expenditure and values are not calculated due to the methodological revision studies since 2010.

From Table 1 the following results can be obtained:

- Food and non-food poverty rates was measured $25.29 \%$ between 2002 and 2005 , it decreased to $18.08 \%$ in 2009 .

- The proportion of population living on less than $1 \$$ a day is $1.20 \%$ between 2002 and 2005. But after 2005, this type of poverty rate was not be measured because there was no one living on less than $1 \$$ a day.

- The proportion of population living on less than $2,15 \$$ a day is $2.36 \%$ in the period of 2002-2005, and it decreased to $0.06 \%$ in 2013 .

- The proportion of population living on less than $4,3 \$$ a day is $22.82 \%$ in the period of 2002-2005, and it decreased significantly by 2013 . The rate decreased from $22.82 \%$ to $2.06 \%$ in 2013 .

- The relative poverty rate based on expenditure was measured $15.14 \%$ between 2002 and 2005. There was not any significant change until 2009. The relative poverty rate based on expenditure was measured $15.12 \%$ in 2009.

Overall we can see that there has been a decline in poverty rates in Turkey over the period under review. 


\subsection{Social Aid and Solidarity Promotion Fund}

The main aim of public provision particularly in the areas of education, health care, social security and protection against hunger should be to ensure that the poor have reasonable access (Ahmad \& Chalk, 1993). A comprehensive set of strategies can be developed by a government to reduce poverty. These strategies may involve "a variety of instruments and complimentary programs such as social grants, unemployment insurance funds, and related public works programs aimed at safeguarding the working poor (HagenZanker \& Morgan, 2011)" (Rapatsa, 2015: 43). The essence of social security is to provide basic needs to poor. Poor may be provided with food, water, health care, energy, free education. Social transfer expenditure may include "child support grant (meant to benefit children under the age of 18 years), foster care grant (paid to parents or guardian of foster children), care in dependency grant (paid to parents of disabled child), old age grant (paid to elderly citizens over 60 years of age), disability grant (allocated to people living with disability) and war veterans grant" (Rapatsa, 2015: 46).

There are several ways to combat poverty, but income transfers and social expenditures seem to be important policy instruments in Turkey. Social Aid and Solidarity Promotion Fund (SASPF) is a special fund established in 1986. The aim of the fund is to help people who do not have any access to pension funds and do not earn any money to live off at all. The fund also helps people in need by using educational supports. Primarily the fund aims at helping poor people directly, but at the same time, since it has some potential to improve income distribution, it plays a very important role at achieving the goal of welfare state (see Social Aid and Solidarity Promotion Fund Law 3294).

As to social benefits of the fund, it ensures the solidarity and unity in the society, and hence people do not depend on each other to live in the society. Thus, people in the society not only keep their lives in wellbeing but also can express themselves as individuals in the society.

There are direct assistances, which have been carried out by using the resources of SASPF. These direct assistances are also called as Social Assistance Programs as it is shown in Table (2). The public assistance programs are categorized in seven different main groups and these main groups have its own assistance as sub-items. These main assistances are respectively; family allowance, health assistance, educational assistance, disabled assistance, special purpose assistance, widow's assistance and assistance programs for military families in need. Food aids, fuel aids and housing assistances are the sub-items of family allowances. Treatment, conditional health, training material, conditional education, lunch and free books assistance, transportation and housing for students, free transportation for disabled students and higher education scholarships are the sub-items of education assistances. Free transportation project for disabled students is the sub-item of disabled assistance. Foodbank and disaster reliefs are the sub-items of special purpose assistance. 
Table: 2

The Direct Assistances within SASPF

\begin{tabular}{|c|c|}
\hline \multicolumn{2}{|c|}{ SOCIAL ASSISTANCE PROGRAMS WITH COMPONENTS } \\
\hline FAMILY ALLOWANCE & $\begin{array}{c}\text { Food Aids } \\
\text { Fuel Aids } \\
\text { Housing Assistance }\end{array}$ \\
\hline HEALTH ASSISTANCE & $\begin{array}{c}\text { Treatment Assistance } \\
\text { Conditional Health Assistance } \\
\end{array}$ \\
\hline EDUCATION ASSISTANCE & $\begin{array}{c}\text { Training Material Assistance } \\
\text { Conditional Education Assistance } \\
\text { Lunch Assistance } \\
\text { Free Books Assistance } \\
\text { Transportation and Housing Assistance for Students } \\
\text { Free Transportation Assistance for Disabled Students } \\
\text { Higher Education Scholarships }\end{array}$ \\
\hline DISABLED ASSISTANCE & Free Transportation Project for Disabled Students \\
\hline SPECIAL PURPOSE ASSISTANCE & $\begin{array}{c}\text { Foodbank } \\
\text { Disaster Reliefs }\end{array}$ \\
\hline WIDOW'S ASSISTANCE & Assistance Program for Widows \\
\hline ASSISTANCE PROGRAM FOR MILITARY FAMILIES IN NEED & Assistance Program for Military Families in Need \\
\hline
\end{tabular}

Source: Table is prepared from Directorate of Social Assistance (SYGM) <http://www.sosyalyardimlar.gov.tr $>$, 20.07.2014.

The council of SASPF makes a decision for the usage and the distribution of fund sources. Then, this decision is submitted to the Prime Minister for the approval to come into force. The council of SASPF is comprised of a president and seven members (see Table 3).

Table: 3

\section{The Council of Social Aid and Solidarity Promotion Fund}

\begin{tabular}{|c|c|c|}
\hline The Council of SASPF & MEMBERS & REPRESENTATIVE \\
\hline President & Ministry Of Family And Social Policies & The Minister Of Family And Social Policies \\
\hline Member & Prime Ministry & Counsellor \\
\hline Member & Ministry Of Family And Social Policies & Counsellor \\
\hline Member & Ministry Of Interior & Counsellor \\
\hline Member & Ministry Of Health & Counsellor \\
\hline Member & Ministry Of Finance & Counsellor \\
\hline Member & General Directorate Of Social Assistance & General Director \\
\hline Member & General Directorate Of Foundations & General Director \\
\hline
\end{tabular}

Source: Table is prepared from Directorate of Social Assistance (SYGM) <http://sosyalyardimlaraile.gov.tr/ hakkimizda/sosyal-yardimlasma-ve-dayanismayi-tesvik-fonu-kurulu>, 20.07.2014.

The president of SASPF Council is the Minister of Family and Social Policies. The members of SASPF Council are the counsellors of Prime Ministry, Ministry of Family and Social Policies, Ministry of Health, Ministry of Finance, and General Directorate of Social Assistance and General Directorate of Foundations. The SASP Fund is allocated to towns and provinces. 973 foundations of Social Aid and Solidarity across cities and towns in Turkey administer this fund.

By inspecting the questionnaires and the social workers' home visit report, the foundations decide how the SASP Fund is distributed among people who require assistance. In general, the board of trustees of SASPF in each town and province evaluates if families and individuals really need help or not according to criteria: The families or 
individuals must not have pensions or covered by any social security; They must not own any land or vehicles; They must not be registered to the Union of Chamber of Merchants and Craftsmen; They must not have any income received. However, in practice, there are exceptions for receiving SASPF supports. One exceptions is, for example, some family members may fulfill requirements for the assistance of SASPF, but they do not receive any support because they have their own mattress savings as gold and money hidden at home. However, the social workers and foundation must discover these savings during the house visit; another exception is that even if some family members or individuals have pensions, they still can benefit from SASPF assistance only for once provided that family members or individuals have serious illness such as a cancer or tuberculosis. This is because even people with pensions cannot afford the treatments of these illnesses, thus they may receive SASPF supports by a committee report (see SYDV 2006).

Recent development of SASPF sub-components is shown in the graph below. The amounts of direct assistances in reel values from 2008 to 2011 are depicted in Graph land it is clear that educational assistance is quite much more than other direct assistances in reel values and increased quite sharply in 2011.

\section{Graph: 1}

Social Assistances (2008-2011)

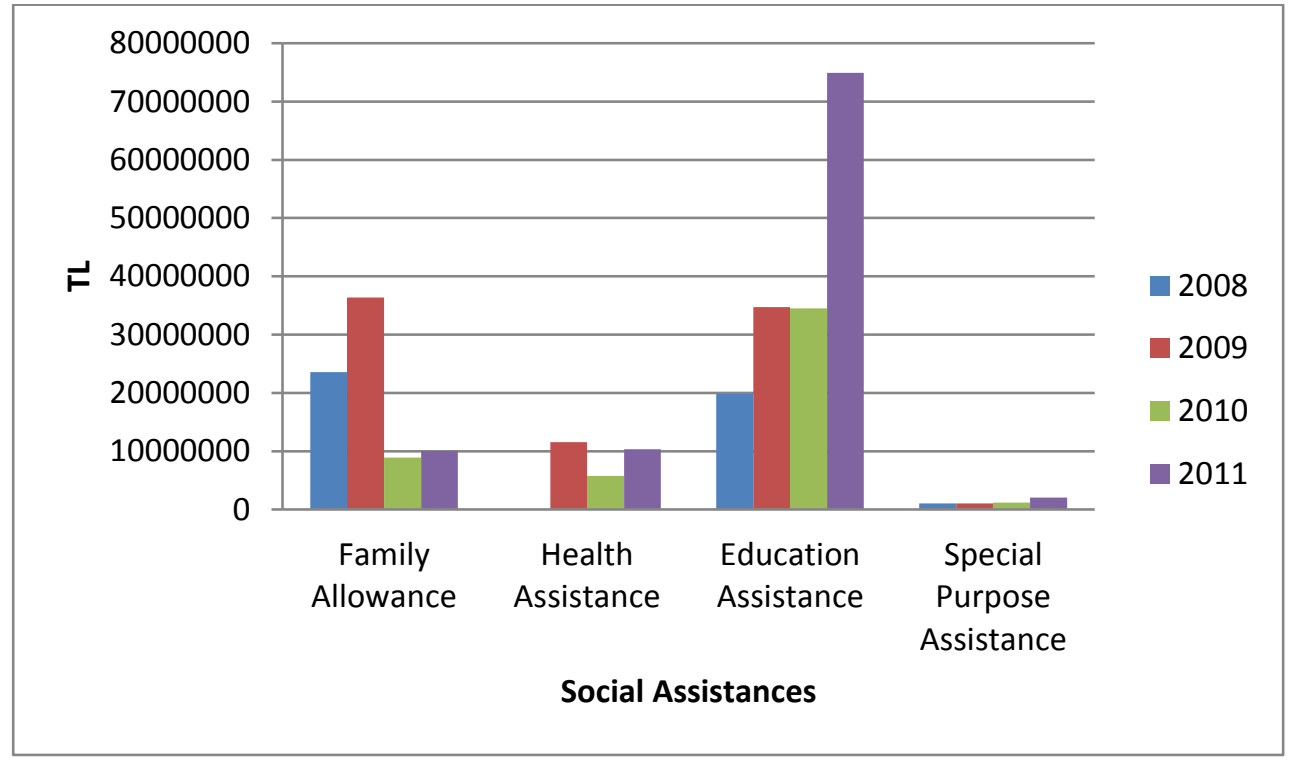

In the next section, the relationship between political variables and "Social Aid and Solidarity Promotion Fund" will be analyzed in the political economy context. We will 
examine whether there is an interaction between political variables and "Social Aid and Solidarity Promotion Fund" and its sub-components used for the struggle against poverty.

\section{Political Economy of Poverty}

Fair (1976) suggested that there is not any factor to affect the election results except growth rates and national income. He found that one percent increase in growth rate raised vote rates of political party in power by one percent. Vergne (2006) analyzed the effect of public expenditures on elections in 42 developing countries by using the data over 1975-2001. He found that public expenditures in election years have been directed to current expenditures such as wage rise and subsidies rather than capital expenditures. There are various studies found the political motivation behind the government expenditures. The approach taken here is also comparable with the literature on the use of intergovernmental grants for political objectives. For example, Guccio and Mazza (2014) argue that a substantial number of empirical studies conclude that decisions concerning the allocation of intergovernmental grants in various countries are politically motivated.

Pop-Eleches and Pop-Eleches (2012) argued that the few existing studies concerned directly with the electoral effects of public expenditure. For example, Samuels (2002) found that pork barrel expenditure in Brazil did not bring greater electoral support. Bruhn (1996) also found weak effects in Mexico. However, Weyland (1998) found that regions with high social expenditure would probably support party in power in Argentina and Peru (Pop-Eleches \& Pop-Eleches, 2012: 288).

Drazen and Eslava (2008) empirically supported the political economy of government spending by using the local fiscal data for all municipalities in Colombia. They found that the pre-election expenditures are mostly shifted to sectors in which voters are able to observe more specifically and politicians with the aim of being re-elected utilize those local expenditures as an incentive.

Guccio and Mazza (2014), while investigating the allocation of funds for cultural heritage conservation to the heritage authorities of regional governments in Sicily, found that the allocation of funding was politically motivated and influenced by the prominence of representatives of the ruling coalition in a district and the loyalty of voters to the main party.

Psycharis et al (2015) discuss how electoral politics shapes the regional allocation of public investment spending in Greece and found that there is a strong relationship between electoral benefits and regional public investment spending. Their results show that leading political parties have tended to reward supporting constituencies. They also found that a region has been rewarded by greater public investment, if both the absolute and relative electoral returns of the leading political party increase in that region. Regions where the leading political party is very strong have been the greatest beneficiaries of this type of pork-barrel politics (Psycharis et al, 2015). 
Barreira and Baleries (2004) emphasized that current expenditures and social transfer payments used for reducing poverty increase faster than capital expenditures on forthcoming electoral periods, and some policies such as tax reduction and tax amnesty are implemented. In political business cycles, politicians are seen as opportunistic agents that have rights to use the fiscal instruments to increase the chance of re-election.

Khemani (2010) searched the political-economic effect of infrastructural investment in India where the proportion of capital expenditures is less than the proportion of infrastructural investments in public budget. He found that increasing infrastructural investment spending was in fact undertaken for political concerns rather than increasing growth or alleviating poverty.

Schady (2000) analyzed the relationship between social transfers and political variables. While aiming to analyze political effects of regional allocation and timing of fund called FONCODES implemented against poverty in Peru during the period of 19911995, Schady obtained three results: The first result is that these expenditures increase dramatically during pre-election periods. Secondly, the results imply that fund projects are mostly directed to provinces with larger marginal political effect. The third result is that funds are allocated to provinces favoring poor ones in order to contribute income distribution. These results prove that the fund can be used for both political and economic objectives. Therefore, it is worth to analyze if the same objectives motivate politicians in Turkey. Next section explores the data and the model used to test the hypothesis.

\subsection{Data and Method}

With uncertainty regarding voting behavior (probabilistic voting), as Guccio and Mazza (2014) we follow Cox and McCubbins (1986) argument about the fundingallocation strategy for incumbent. Cox and McCubbins (1986) argues that "public spending will be chosen to reward voters loyal to the government. Risk averse legislators distribute funds to reward the constituency with the highest expected electoral return, who are the core supporters with less uncertain about voting behavior" (excerpted from Guccio \& Mazza, 2014: 20).

In Turkey, the high concentration of representatives of the ruling party in one province may have a positive influence on special fund assigned to the foundation in that province; because a political party wishing to reward its representatives would find it effective to allocate funds to those provinces where more its parliament members have been elected. This leads to following hypothesis:

H. Provinces with a higher number of leading political party representatives (or higher ratio of votes/higher number of votes cast for JDP) obtain a higher amount of funds. 
The fund is estimated as a simple linear function of our political and economic variables. The model employed in this study is:

$$
\text { Fund }_{i}=\beta_{0}+\beta_{i} P_{i}+\alpha_{i} X_{i}+\varepsilon_{i}
$$

Political determinants i.e., vector $\mathrm{P}$ in the equation, are the variables of interest. Economic determinants, vector $\mathrm{X}$ in the equation, are used as the control variables. Here all variables are in logarithmic forms and are defined as:

$\begin{array}{llll}- & \text { Fund } & : & \text { Dependent Variable (SASPF) } \\ - & \mathrm{P} & : & \text { Vector of Political Variables (V, VR, MP) } \\ - & \mathrm{X} & : & \text { Vector of Economic Variables (PCY, U, GC) } \\ - & \mathrm{E} & : & \text { Error Term } \\ - & \mathrm{i} & : & 1, \ldots 81 \text { provinces }\end{array}$

The vectors of $\beta$ and $\alpha$ include the parameters that measure the effects of the political and exogenous variables, respectively. Economic factors are used to catch the effect of the social programs on reducing poverty. These variables are $U$ (unemployment), GC (green card), and Y (per capita income). We expect that if $U$ and GC are high in the region there will be more need to spend for poor people in that region. On the other hand, per capita income level captures whether the region is poor or not. Thus we expect that the poorer the region is the more fund is going to be spend in that region.

The purpose of the econometric model is to determine the relationship between political variables, "Social Aid, and Solidarity Promotion Fund" which is a direct strategy to reduce poverty in Turkey. In this context, the dependent variables used in the econometric models are explained below and the data sources are given;

Dependent Variables are:

A: The Payments of Social Aid and Solidarity Promotion Fund in 2011

PER: Periodical Payments in 2011

HOM: Family Payments in 2011

EDU: Education Payments in 2011

HEA: Health Payments in 2011

Data on dependent variables are obtained from Directorate of Social Assistance's (2011) operation report. Data on independent variables are obtained from Iliman (2014). 
Although the influence of politics could also be measured by comparing party affiliation between central and local government, we did not measure the influence of politics in this way. Because the special fund is not allocated to the local government, it is rather spent by government agencies called the Foundation of Social Aid and Solidarity Promotion located in each province and town. Instead, we used the number of votes and the percentage of votes in each province cast for the political party formed the government and the political representation of province at the national assembly. Independent Variables used in the econometric models are shown below with the expected sign given in the parenthesis:

V (+): Total number of votes cast for Justice and Development Party (JDP) in General Election in 2007

VR (+): The ratio of vote cast for JDP in general election in 2007

MP (+): The number of deputy of JDP in general election in 2007

$\mathrm{U}(+)$ : The unemployment rate in 2010

GC (+): The number of green card at the level of each province in 2008

PCY (-): The per capita gross domestic product at the level of each province in 2001 (latest available data).

Table: 4

\section{Variables and Expected Signs in Models}

\begin{tabular}{|c|c|c|c|c|c|c|c|c|c|c|c|c|c|c|c|}
\hline Depedent variables & I & II & III & IV & $\mathrm{V}$ & VI & VII & VIII & IX & $\mathrm{X}$ & XI & \begin{tabular}{|l|} 
XII \\
\end{tabular} & \begin{tabular}{|l|} 
XII \\
\end{tabular} & \begin{tabular}{|l|} 
XIV \\
\end{tabular} & $\mathrm{XV}$ \\
\hline LnA & $\sqrt{ }$ & & & & & $\sqrt{ }$ & & & & & $\sqrt{ }$ & & & & \\
\hline LnPER & & $\sqrt{ }$ & & & & & $\sqrt{ }$ & & & & & $\sqrt{ }$ & & & \\
\hline LnHOM & & & $\sqrt{ }$ & & & & & $\sqrt{ }$ & & & & & $\sqrt{ }$ & & \\
\hline LnEDU & & & & $\sqrt{ }$ & & & & & $\sqrt{ }$ & & & & & $\sqrt{1}$ & \\
\hline LnHEA & & & & & $\sqrt{ }$ & & & & & $\sqrt{ }$ & & & & & $\sqrt{ }$ \\
\hline \multicolumn{16}{|l|}{ Independent variables } \\
\hline $\ln V$ & + & + & + & + & + & & & & & & & & & & \\
\hline $\ln V R$ & & & & & & + & + & + & + & + & & & & & \\
\hline lnMP & . & & & & & & & & & & + & + & + & + & + \\
\hline $\operatorname{lnPCY}$ & - & - & - & - & - & - & - & - & - & - & - & - & - & - & - \\
\hline $\operatorname{lnU}$ & + & + & + & + & + & + & + & + & + & + & + & + & + & + & + \\
\hline $\operatorname{lnGC}$ & + & + & + & + & + & + & + & + & + & + & + & + & + & + & + \\
\hline
\end{tabular}

Note: Since the JDP does not have any deputy in the province of Tunceli, the province of Tunceli is not included

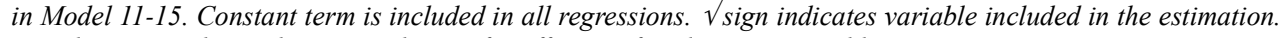
+ and - signs indicate the expected sign of coefficient of explanatory variable.

The effect of independent variables on dependent variable has been tested with OLS generating 15 different econometric models. When the econometric models are formed, both dependent and independent variables are taken in logarithmic form. Also, highly correlated variables are not used in the same regression: for instance V, VR and MP. 
Breusch-Pagan/Cook-Weisberg test is used to see whether there is a heteroscedasticity problem or not. The result implies that there is a heteroscedasticity problem in some models. Therefore, we did the VIF test but it was not exceeding 10 which means that the heteroscedasticity is not a problem. Thus, the models are estimated by taking account of the heteroscedasticity problem.

\subsection{Results}

The estimation results are presented in the tables below. Overall, we find that while the fund is allocated mostly to the region in need (measured with income level and unemployment), there are also political factors important in fund allocation to the provinces.

In Model 1, the relationship between the total payments of social aid and solidarity promotion fund (A) and total number of votes of Justice and Development Party (V), per capita income level (PCY), the unemployment rate(U), the green card number (GC) is tested. Variables V, PCY and U are correctly signed and significant. The coefficient of $\mathrm{V}$ is statistically significant at the conventional $1 \%$ significance level. It indicates that a $1 \%$ increase in the number of votes cast for JDP in general election will result in a $0.70 \%$ increase in the province's fund receipts.

\section{Table: 5}

\section{Estimation Results}

\begin{tabular}{|c|c|c|c|}
\hline \multirow[b]{2}{*}{ Explanatory Variables } & \multicolumn{3}{|c|}{$\begin{array}{l}\text { Dependent Variable: } \\
\ln A\end{array}$} \\
\hline & Model 1 & Model 2 & Model 3 \\
\hline Constant & $\begin{array}{l}13.67 * * * * \\
(0.000) \\
\end{array}$ & $\begin{array}{l}14.94 * * * \\
(0.000) \\
\end{array}$ & $\begin{array}{l}18.97 * * * * \\
(0.000)\end{array}$ \\
\hline $\ln \mathrm{V}$ & \begin{tabular}{|l|}
$0.70^{* * * * *}$ \\
$(0.000)$ \\
\end{tabular} & - & - \\
\hline $\operatorname{lnVR}$ & - & $\begin{array}{ll}0.37 \\
(0.101)\end{array}$ & - \\
\hline $\operatorname{lnMP}$ & - & - & $\begin{array}{l}0.84^{* * * *} \\
(0.000)\end{array}$ \\
\hline $\operatorname{lnPCY}$ & \begin{tabular}{|l|}
$-0.98 * * * *$ \\
$(0.000)$ \\
\end{tabular} & $\begin{array}{l}-0.39 * * \\
(0.036) \\
\end{array}$ & $\begin{array}{l}-0.68 * * * * \\
(0.000)\end{array}$ \\
\hline $\ln U$ & $\begin{array}{l}0.58^{* *} \\
(0.002)\end{array}$ & $\begin{array}{l}0.67 * * \\
(0.026)\end{array}$ & $\begin{array}{l}0.56^{* * *} \\
(0.006)\end{array}$ \\
\hline $\operatorname{lnGC}$ & \begin{tabular}{|l|}
0.04 \\
$(0.400)$
\end{tabular} & $\begin{array}{l}0.14 \\
(0.134)\end{array}$ & $\begin{array}{l}0.03 \\
(0.607)\end{array}$ \\
\hline R-Squared & \begin{tabular}{|l|}
0.69 \\
\end{tabular} & 0.22 & 0.64 \\
\hline $\begin{array}{l}\text { F-Statistic } \\
\text { (df) }\end{array}$ & \begin{tabular}{|l}
$42.45 * * *$ \\
$(4,75)$ \\
\end{tabular} & $\begin{array}{l}5.51^{* * * *} \\
(4,75) \\
\end{array}$ & $\begin{array}{l}33.34 * * * \\
(4,75)\end{array}$ \\
\hline$\chi^{2}$ HET & $\begin{array}{l}0.82 \\
{[0.365]}\end{array}$ & $\begin{array}{l}0.32 \\
{[0.571]}\end{array}$ & $\begin{array}{l}1.39 \\
{[0.237]}\end{array}$ \\
\hline
\end{tabular}

$* * *, * *$ and $*$ denote statistical significance at the 1\%, 5\% and $10 \%$ level, respectively. The number of observation is 80; $\chi^{2}{ }_{\text {HET }}$ is the test for no heteroscedasticity based on the $\chi^{2}$ distribution; Values in parenthesis are p-values; $F$-statistic is overall significance of the model with degrees of freedom given in parenthesis.

We also found that the political variable MP is positively related to the amount of fund allocated. The political representation of a province increases the fund to the 
province by $0.84 \%$. The coefficient of the variable VR is positive but statistically insignificant. On the other hand, a $1 \%$ increase in a region's unemployment level will result in almost a $0.58 \%$ increase in the province's fund receipt. Also, if the per capita income is low in a province there will be more funds spend in that province. The coefficient of PCY is -0.98 and it is statistically significant at the conventional $1 \%$ significance level. Model 2 and 3 contained the same independent variables as in column 1, except that the political variables VR and MP are substituted for V in a separate estimation. The signs of economic variables remain the same. We still have the political factors important in the distribution of funds (in Model 3).

The results on regression of fund's components on the independent variables are displayed in Table 6. The models contain the same independent variables as in Table 5 except that sub-payments are substituted for the total funds (A). While political variables V and MP are correctly signed and significant, VR was found positive but statistically insignificant.

In Model 4 to 6 , the relationship between periodical payments and politicaleconomic variables is tested. The only significant variables here are political variables $\mathrm{V}$ and MP. The economic variables are not statistically significant. It seems that a one percent increase in the number of votes of JDP in general election led to a positive rise in periodical payments by $0.84 \%$.

In Model 7 to 9, the relationship between family payments and the number of votes of JDP in general election, the per capita income, the unemployment rate, the green card number is tested. The coefficients of political variables V and MP are positive and statistically significant. Only one economic variable (i.e. per capita income) was found to be statistically significant in the model 7 . We find that a $1 \%$ increase in the number of votes of JDP in general election led to a positive rise in family payments by $0.62 \%$. Also, if the income level of province increases, it reduces the family payments by $0.44 \%$ meaning that poorer the region is the more the fund is spent in that region.

In Model 10 to 12, the relationship between education payments and political economic factors is tested. We find that one percent increase in the total number of votes cast for JDP in general election led to a positive rise in education payments by 0.80 percent. Also, a percentage decrease in PCY at the level of each province led to a positive direction in education payments by $1.40 \%$. In addition, one percent increase in the unemployment rate at the level of each province led to a positive rise in education payments by $0.92 \%$. When we substituted the political variable MP for V the results does not change much. It seems that political variable (MP) has a positive effect on education payments: a $1 \%$ increase in the number of deputy of JDP in general election led to a positive rise in education payments around $0.97 \%$. When we used VR as a political variable, it has correct sign but statistically insignificant coefficient. The unemployment level of province is positively correlated with the fund receipt. However, in none of the estimation the variable GC is found to be statistically significant. 


\section{Table: 6 (continued)}

\section{Estimation Results}

\begin{tabular}{|c|c|c|c|c|c|c|c|c|c|c|c|c|}
\hline & \multicolumn{3}{|c|}{ Dependent Variable InPER } & \multicolumn{3}{|c|}{ Dependent Variable InHOM } & \multicolumn{3}{|c|}{ Dependent Variable InEDU } & \multicolumn{3}{|c|}{\begin{tabular}{|l|} 
Dependent Variable InHEA \\
\end{tabular}} \\
\hline Explanatory variables & Model 4 & Model 5 & Model 6 & Model 7 & Model 8 & Model 9 & \begin{tabular}{|l|} 
Model 10 \\
\end{tabular} & Model 11 & \begin{tabular}{|l|} 
Model 12 \\
\end{tabular} & \begin{tabular}{|l|} 
Model 13 \\
\end{tabular} & Model 14 & \begin{tabular}{|l|} 
Model 15 \\
\end{tabular} \\
\hline Constant & $\begin{array}{l}8.39 * \\
(0.095)\end{array}$ & $\begin{array}{l}13.19 * * \\
(0.030)\end{array}$ & $\begin{array}{l}14.89 * * * \\
(0.003)\end{array}$ & $\begin{array}{l}9.43^{* * * * *} \\
(0.000)\end{array}$ & $\begin{array}{l}11.10 * * * \\
(0.000)\end{array}$ & $\begin{array}{l}14.05 * * * * \\
(0.000)\end{array}$ & \begin{tabular}{|l}
$13.43 * * * *$ \\
$(0.000)$ \\
\end{tabular} & $\begin{array}{l}15.55^{* * * *} \\
(0.000)\end{array}$ & \begin{tabular}{|l}
$19.45^{* * * * *}$ \\
$(0.000)$ \\
\end{tabular} & \begin{tabular}{|l}
$17.58 * * * *$ \\
$(0.000)$ \\
\end{tabular} & $\begin{array}{l}19.86^{* * * *} \\
(0.000)\end{array}$ & \begin{tabular}{|l}
$24.98^{* * * *}$ \\
$(0.000)$ \\
\end{tabular} \\
\hline $\operatorname{LnV}$ & $\begin{array}{l}0.84 * * * * \\
(0.004) \\
\end{array}$ & - & - & \begin{tabular}{|l}
$0.62^{* * * * *}$ \\
$(0.000)$ \\
\end{tabular} & 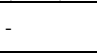 & - & \begin{tabular}{|l|}
$0.80^{* * * *}$ \\
$(0.000)$ \\
\end{tabular} & - & - & \begin{tabular}{|l|}
$0.97^{* * * *}$ \\
$(0.000)$ \\
\end{tabular} & - & 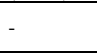 \\
\hline LnVR & - & $\begin{array}{l}-0.25 \\
(0.703) \\
\end{array}$ & - & - & $\begin{array}{l}0.21 \\
(0.272) \\
\end{array}$ & - & 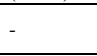 & $\begin{array}{l}0.28 \\
(0.317) \\
\end{array}$ & - & 2 & $\begin{array}{l}0.40 \\
(0.371) \\
\end{array}$ & $\mid-$ \\
\hline LnMP & - & - & $\begin{array}{l}1.08^{\text {***** }} \\
(0.004)\end{array}$ & - & - & $\begin{array}{l}0.72^{* * * *} \\
(0.000)\end{array}$ & - & - & \begin{tabular}{|l|}
$0.97^{\text {****** }}$ \\
$(0.000)$ \\
\end{tabular} & - & - & $\begin{array}{l}1.21^{* * * *} \\
(0.000) \\
\end{array}$ \\
\hline $\operatorname{lnPCY}$ & $\begin{array}{l}-0.14 \\
(0.801)\end{array}$ & $\begin{array}{l}0.46 \\
(0.400)\end{array}$ & $\begin{array}{l}0.20 \\
(0.692)\end{array}$ & \begin{tabular}{|l|}
$-0.44 * * * *$ \\
$(0.000)$ \\
\end{tabular} & $\begin{array}{l}0.06 \\
(0.695)\end{array}$ & $\begin{array}{l}-0.16 \\
(0.131)\end{array}$ & \begin{tabular}{|l|}
$-1.40^{\text {***** }}$ \\
$(0.000)$ \\
\end{tabular} & $\begin{array}{l}-0.75 * * * \\
(0.001) \\
\end{array}$ & $-1.05 * * *(0.000)$ & \begin{tabular}{|l|}
$-2.49^{* * * *}$ \\
$(0.000)$ \\
\end{tabular} & $\begin{array}{l}-1.70 * * * \\
(0.000)\end{array}$ & \begin{tabular}{|l|}
$-2.09^{\text {***** }}$ \\
$(0.000)$ \\
\end{tabular} \\
\hline LnU & $\begin{array}{l}-1.05 \\
(0.205) \\
\end{array}$ & $\begin{array}{l}-1.09 \\
(0.216) \\
\end{array}$ & $\begin{array}{l}-1.07 \\
(0.193) \\
\end{array}$ & $\begin{array}{l}0.22 \\
(0.141) \\
\end{array}$ & $\begin{array}{l}0.28 \\
(0.281) \\
\end{array}$ & $\begin{array}{l}0.20 \\
(0.234) \\
\end{array}$ & $\begin{array}{l}0.92^{* * * *} \\
(0.000) \\
\end{array}$ & $\begin{array}{l}0.99 * * * \\
(0.008)\end{array}$ & \begin{tabular}{|l|}
$0.90^{\text {***** }}(0.001)$ \\
\end{tabular} & $\begin{array}{l}1.39^{* * * *} \\
(0.005) \\
\end{array}$ & $\begin{array}{l}1.49^{* *} \\
(0.013) \\
\end{array}$ & \begin{tabular}{|l|}
$1.36^{* * * *}$ \\
$(0.007)$ \\
\end{tabular} \\
\hline LnGC & $\begin{array}{l}0.04 \\
(0.867)\end{array}$ & $\begin{array}{l}0.20 \\
(0.466)\end{array}$ & $\begin{array}{l}0.01 \\
(0.961)\end{array}$ & $\begin{array}{l}0.008 \\
(0.857)\end{array}$ & $\begin{array}{l}0.09 \\
(0.232)\end{array}$ & $\begin{array}{l}-0.002 \\
(0.967)\end{array}$ & $\begin{array}{l}0.04 \\
(0.609)\end{array}$ & $\begin{array}{l}0.15 \\
(0.184)\end{array}$ & $\begin{array}{l}0.02 \\
(0.809)\end{array}$ & $\begin{array}{l}-0.04 \\
(0.759)\end{array}$ & $\begin{array}{l}0.08 \\
(0.642)\end{array}$ & $\begin{array}{l}-0.07 \\
(0.616)\end{array}$ \\
\hline R-Squared & 0.12 & 0.02 & 0.13 & 0.67 & 0.07 & 0.57 & 0.65 & 0.27 & 0.62 & 0.51 & 0.31 & 0.51 \\
\hline $\begin{array}{l}\text { F-Statistic } \\
\text { (df) }\end{array}$ & $\begin{array}{l}2.77 * * \\
(4,75)\end{array}$ & $\begin{array}{l}0.57 * \\
(4,75)\end{array}$ & $\begin{array}{l}2.83^{* * *} \\
(4,75)\end{array}$ & \begin{tabular}{|l|}
$38.48 * * * *$ \\
$(4,75)$ \\
\end{tabular} & $\begin{array}{l}1.58^{* * *} \\
(4,75)\end{array}$ & $\begin{array}{l}25.08^{* * * * *} \\
(4,75)\end{array}$ & \begin{tabular}{|l|}
$35.97 * * * *$ \\
$(4,75)$ \\
\end{tabular} & $\begin{array}{l}7.25 * * * * \\
(4,75)\end{array}$ & \begin{tabular}{|l|}
$30.95^{\text {***** }}$ \\
$(4,75)$ \\
\end{tabular} & \begin{tabular}{|l|}
$20.16 * * * *$ \\
$(4,75)$ \\
\end{tabular} & $\begin{array}{l}8.54 * * * * \\
(4,75)\end{array}$ & \begin{tabular}{|l|}
$19.74 * * * *$ \\
$(4,75)$ \\
\end{tabular} \\
\hline$\chi^{2}$ нЕт & $\begin{array}{l}59.76 \\
{[0.000]}\end{array}$ & $\begin{array}{l}103.66 \\
{[0.000]}\end{array}$ & $\begin{array}{l}75.95 \\
{[0.000]} \\
\end{array}$ & \begin{tabular}{|l|}
10.33 \\
{$[0.001]$} \\
\end{tabular} & $\begin{array}{l}1.58 \\
{[0.208]} \\
\end{array}$ & $\begin{array}{l}11.67 \\
{[0.000]} \\
\end{array}$ & \begin{tabular}{|l|}
1.80 \\
{$[0.180]$} \\
\end{tabular} & $\begin{array}{l}0.81 \\
{[0.368]} \\
\end{array}$ & \begin{tabular}{|l|}
0.33 \\
{$[0.563]$} \\
\end{tabular} & \begin{tabular}{|l|}
0.10 \\
{$[0.750]$} \\
\end{tabular} & $\begin{array}{l}0.00 \\
{[0.969]}\end{array}$ & \begin{tabular}{|l|}
0.01 \\
{$[0.929]$} \\
\end{tabular} \\
\hline
\end{tabular}

Note: ***,**and * denote statistical significance at the 1\%, 5\% and 10\% level respectively. The number of observation is 80 ; $\chi^{2}$ HET is the test for no heteroscedasticity based on the $\chi^{2}$ distribution. Values in parenthesis are p-values; F-statistic is overall significance of the model with degrees of freedom given in parenthesis. 
In Model 13 to 15, the relationship between health payments and our economic political factors is tested. In Model 13, the variable V is significant with a positive sign and if the total number of votes cast for JDP in general election increase by $1 \%$, health payments increase on average by $0.97 \%$. Also, a percentage decrease in per capita income in each province increases health payments by $2.49 \%$. In addition, a $1 \%$ increase in the unemployment rate at the level of each province increases health payments by $1.39 \%$.

In Model 14, we used the vote rates of JDP in general election as a political variable. However, it is not statistically significant. In Model 15, we used the number of deputy of JDP in general election as a political variable and it is statistically significant. Its coefficient indicates that a $1 \%$ increase in the number of deputy of JDP in general election increases health payments by $1.08 \%$. Also, a percentage decrease in GDP at the level of each province increases health payments by $2.09 \%$. We can also say that a $1 \%$ increase in the unemployment rate at the level of each province increases health payments by $1.36 \%$.

Overall, our findings suggest that while the fund was spent in the region where the needs were higher, the government was also concerned with the political capital in that region as well.

\section{Conclusion}

Poverty alleviation is one of the important policy objectives in both developed and developing welfare states. There are two specific policy instruments called as "direct" and "indirect" approaches to fight against poverty. The indirect approach against poverty stresses that poverty could be alleviated by economic growth. The indirect approach aims at enhancing the income and living standards of poor people through rapid economic growth. On the other hand, the main purpose of direct way to combat poverty is to ensure the fair redistribution of income by using the fiscal policy instruments (Kanbur et al., 1994: 191). Governments strive for alleviating poverty by treating the secondary income distribution effectively through fiscal policy instruments such as tax policy, social security policy, education policy and health policy (Arpacioglu \& Yıldırım, 2011: 72).

In this study, we focused on the issue of struggle against poverty in Turkey. The Ministry of Family and Social Policies has a power laid down by the laws, and maintains its primary goal, which is poverty reduction as an authorized body. In order to achieve its main task the Ministry is empowered with the special fund called as "Social Aid and Solidarity Promotion Fund".

We can assert that the special fund as social expenditure was spent at the government' discretion in Turkey. Although there are some restrictions on government for using the fund arbitrarily, the political party forming the government can use the fund to maximize its political interests. Accordingly, we have empirically examined the relationship between "The Social Aid and Solidarity Promotion Fund" and "political economic variables". For that purpose, we have formed 15 different econometric models 
by using the cross section data on Social Aid and Solidarity Promotion Fund and its subitems in all 81 provinces in Turkey. Most of our estimation results show that the variables are of expected sign and statistically significant.

In conclusion, we have found that there is a statistically significant relationship between political variables (i.e. the governing party's (JDP) total number of votes and number of deputies of JDP in general election), and dependent variables the total payments of the fund and other sub-payments (periodical, family, education and health payments). Moreover, there is also statistically significant relationship between economic variables (the GDP and the unemployment rates at level of each province) and our dependent variable. Therefore, the fact that political factors are statistically significant on fund allocation along with the economic factors is an indication that politicians are motivated to maximize their special interests. Our findings suggest that the funds are mostly allocated to the provinces where the leading political party is strong. The results support the political economy hypothesis: risk averse politicians allocate the funds to reward the constituency with the highest expected electoral return, who are the core supporters. Therefore, the fiscal instruments like social transfer expenditures could be a device for motivating the politicians to maximize their own interests though the goal of alleviating the poverty is amid leading government parties' aims.

\section{References}

Ahmad, E. \& N. Chalk (1993), “On Improving Public Expenditure Policies for the Poor: Major Informational Requirements", IMF Working Paper (WP/93/43), IMF Fiscal Affairs Department.

Arpacıoğlu, Ö. \& M. Yıldırım (2011), “The Analyze of Poverty in Turkey and in World”, Faculty of Economics and Administrative Sciences's Journal of Niğde University, 4(2), 60-76.

Barreira, A. \& N. Baleiras (2004), Elections and the Public Expenditure Mix, <www.researchgate.net/publication/23731189_Elections_and_the_public_expendinture_ $\operatorname{mix}>, 30.10 .2015$.

Baulch, B. (2006), "The New Agenda: A Disputed Concensus”, IDS Bulletin, 37(4), 82-90.

Beker, V.A. (2016), Growth, inequality and poverty: what do we know?, February 3, <http://ssrn.com/abstract=2727231>, 25.09.2015.

Besley, T. \& M. Ghatak (2004), "Public Goods and Economic Development", Reprinted in Understanding Poverty, by A.V. Banerjee, R. Benabou, D. Mookherjee (eds.), Oxford University Press; Oxford, <http://personal.lse.ac.uk/GHATAK/public.pdf〉, 12.06.2015.

Besley, T. (1996), "Political Economy of Alleviating Poverty Theory and Institutions", Annual World Bank Conference Development Economics, Edited by Michael Bruno and Boris Pleskovic, the World Bank Washington, D.C.

Bhagwati, J.N. (1988),’Poverty and Public Policy”, World Development, 16(5), 539-555.

Bruhn, K. (1996), "Social Spending and Political Support: The "Lessons" of the National Solidarity Program in Mexico", Comparative Politics, 28(2), 151-177. 
Bruno, M. \& S. Lyn \& M. Ravallion (1995), "Equity and Growth in Developing Countries: Old and New Perspectives", Policy Research Working Paper 1563, World Bank, Washington D.C.

Caminada, K. \& K. Goudswaard \& F. Koster (2012), "Social income transfers and poverty: A crosscountry analysis for OECD countries", International Journal of Social Welfare, 21(2), $115-126$.

Coudouel, A. \& H. Jesko \& W. Quentin (2002), "Poverty Measurement and Analysis", Handbook on Poverty and Inequality, ed. J. Haughton \& S.R. Khandker, The World Bank, Washington, 27-74.

Cox, G.W. \& M.D. McCubbins (1986), "Electoral politics as a redistributive game”, Journal of Politics, 48, 370-389.

Danziger, S.H. \& D.H. Weinberg (1994), "The Historical Record: Trends in Family Income, Inequality, and Poverty”, in: Confronting Poverty Prescriptions for Change, H.H. Danziger \& G.D. Sandefur \& D.H. Weinberg (eds), Harvard University Press Cambridge, Massachusetts, and London, England.

Dash, B. \& R. Bhusana \& V. Angara (2012), "Political Determinants of the Allocation of Public Expenditures: A Study of the Indian States", Working Paper No. 2012-101, March, National Institute of Public Finance and Policy, New Delhi, <http://www.nipfp.org.in>, 13.02.2015.

Datt, G. \& M. Ravallion \& R. Murgai (2016), "Growth, Urbanization and Poverty Reduction in India”, NBER Working Paper Series 21983, <http://www.nber.org/papers/w21983>, 15.06.2015.

Directorate of Social Assistance (2011), 2011 Yılı Faaliyet Raporu, Aile ve Sosyal Politikalar Bakanlığı Sosyal Yardımlar Genel Müdürlüğü.

Drazen, A. \& M. Eslava (2010), "Electoral Manipulation via Voter-Friendly Spending: Theory and Evidence", Journal of Development Economics, 92(1), 39-52.

Fair, C. (1976), "The Effect of Political Events on Votes for President", The Review of Economics and Statistics, 60(2), 159-173.

Foxley, A. (2004), "Successes and Failures in Poverty Eradication: Chile”, Scaling Up Poverty Reduction: A Global Learning Process and Conference, Shanghai, May 25-27.

Goedhart, T. \& V. Halberstadt \& A. Kapteyn \& B. van Praag (1977), "The Poverty Line: Concept and Measurement", The Journal of Human Resources, 12(4), 503-520.

Guccio, C. \& I. Mazza (2014), "On the political determinants of the allocation of funds to heritage authorities", European Journal of Political Economy, 34, 18-38.

Hagen-Zanker, J. \& J. Morgan (2011), South Africa's social security system: Expanding coverage of grants and limiting increases in equality, Overseas Development Institute, UK: London.

Heady, C. \& T. Mitrakos \& P. Tsakloglou (2001), "The Distributional Impact of Social Transfers in the European Union: Evidence from the ECHP”, IZA Discussion Paper No. 356, September.

Housseima, G. \& J. ben Rejeb (2012), "Poverty, Growth and Inequality in Developing Countries", International Journal of Economic and Financial Issues, 2(4), 470-479.

Ilıman, T. (2014), “Türkiye'de Yoksullukla Mücadelede Fonlar”, Adnan Menderes Üniversitesi Sosyal Bilimler Enstitüsü, Yüksek Lisans Tezi, 2014. 
Kanbur R. \& M. Keen \& M. Tuomala (1994), "Labor Supply and Targeting in Poverty Alleviation Programs", World Bank Economic Review, 8(2), 191-211.

Kehler, J. (2001), "Women and Poverty: The South African Experience", Journal of International Women's Studies, 3(1), 41- 53.

Kenworthy, L. (1999), "Do Social-Welfare Policies Reduce Poverty? A Cross-National Assessment”, Social Forces, March 77(3), 1119-39.

Khemani, S. (2010), "Political Economy of Infrastructure Spending in India”, Policy Research Working Paper 5423, The World Bank.

Pop-Eleches, C. \& G. Pop-Eleches (2012), “Targeted government spending and political preferences", Quarterly Journal of Political Science, 7, 285-320.

Psycharis, Y. \& A Rodriguez-Pose \& V. Tselios (2015), Politics and investment: examining the territorial allocation of public investment in Greece, DP10422 February.

Rapatsa, M. (2015), "Poverty: A socio-economic threat to sustainable development as envisioned by South Africa's transformative regime", EuroEconomica, 2(34), 41-48.

Ravallion, M. (1995), "Growth and poverty: Evidence for developing countries in the 1980s", Economics Letters, Elsevier, 48(3), 411-417.

Samuels, D.J. (2002), "Pork Barreling is not Credit Claiming or Advertising: Campaign Finance and the Sources of the Personal Vote in Brazil", The Journal of Politics, 64(3), 845-863.

Schady, N.R. (2000), "The Political Economy of Expenditures by the Peruvian Social Fund (FONCODES), 1991-95”, American Political Science Association, 94(2), 289-304.

SYDV (2006), Sosyal Yardımlaşma ve Dayanışma Vakıfları Başvuru İnceleme Değerlendirme Dağıtım ve Teslim Usul ve Esaslarl, Temmuz.

TurkStat (2013), Poverty Study, <http://www.tuik.gov.tr/ PreTablo.do?alt_id=101>, 10.06.2013.

Vergne, C. (2009), "Democracy, Elections and Allocation of Public Expenditure in Developing Countries", European Journal of Political Economy, 25(1), 63-77.

Walton, M. (1990), Combating Poverty: Experience and Prospects Finance \& Development, September; International Monetary Fund.

Weyland, K. (1998), "Swallowing the Bitter Pill: Sources of Popular Support for Neoliberal Reform in Latin America", Comparative Political Studies, 31(5), 539-567. 